\title{
Studying Soil Catena in Arid-zone Environment: Case Study for Soil Science Students
}

\author{
Said S. AL-Ismaily ${ }^{1 *} \&$ Ali K. AL-Maktoumi² \\ ${ }^{1}$ Said S. AL-Ismaily, Sultan Qaboos University, Muscat, Sultanate of Oman. ${ }^{2}$ P.O. Box 34, Al-Khod 123, Sultan \\ Qaboos University, Sultanate of Oman
}

Received: July 27, 2010 / Accepted: November 2, 2010

\begin{abstract}
$S_{s t}$ tudying soils under their natural habitat is an important step to understand soil-landscape relationships. Combining field-work with laboratory analyses is an important technique for learning about soils and should help students to broaden their understanding of the basic concepts of soil science and in particular of soil formation. This work provides a detailed procedure for a hands-on educational approach consisting of a field exercise combined with basic laboratory techniques for studying a soil catena. The work involves field study of physical and morphological properties of soil pedons existing on a soil catena of Al-Batinah region, Oman. Soil samples were collected for laboratory analyses. The paper provides a package of field, laboratory, and data analysis exercise using the concept of soil catena or toposequence for studying factors of soil formation in an arid-zone environment. Combining field work with basic laboratory analyses maximizes the benefits of studying soil-landscape relationships.
\end{abstract}

Keywords: Soil education, field exercise, Soil catena, and soil formation factors.

\section{Introduction}

People's concept of soil depends on their direct experience with it. Hence, for soil science students and others interested in pedology, studying soils in their natural environment is a must. Examining soils in their natural condition should broaden students' understanding of the factors responsible for the formation of different types of soils (Weil, 2003). Studying a soil catena in the field with the aid of laboratory analyses enhances understanding of soil-landscape relationships. Soil catena or toposequence defined as a group of different soils that occur

*Corresponding Author: esmaily@squ.edu.om together on a landscape having the same parent material with topography as the dominant influencing factor responsible for the differences existing in such soils (Jenny, 1941).

Examining a soil catena in the field is a good opportunity for students to observe the influence of topography on soil formation, as integrated with parent material, organisms, climate, and time. Field study of a catena juxtaposed with laboratory analysis of collected soil samples will also expose students to basic physico-chemical properties and morphological features for each soil in the catena. In fact, studying soil properties in the field provides a logic in situ framework that helps students to see the influence of soil formation factors that correlate such soil properties as texture, color, and salt content. The approach outlined here involves field work with basic laboratory analyses of soils of aridic soil moisture conditions. We recommend such an exercise for final year soil science students or others interested in gaining experience in the field of pedology, land assessment, geotechnical (geomechanical engineering), among others.

The main objectives of this learning experience were:

\footnotetext{
- To show the impact of human activities besides topography on soil formation and development along a soil catena of an arid zone climate.

- To gain practical and hands-on experience in describing and classifying soils.

- To educate students on how to discuss, interprete, and present the information gained from the practical work into a technical report
}

On successful completion of this study, the students were able to:

- Understand the concepts behind soil variation over a wide 
range of ecosystems along the soil catena.

- Apply the basic principles of soil sciences in understanding soil-landscape relationships.

- Apply the theory and skills gained from this course in issues related to soil environment and land use.

- Have basic understanding in projects that required the preparation of soil national database for land resources planning in Oman.

\section{Materials and Methods}

Al-Batinah region of Oman is an alluvial accumulation plain approximately $270 \mathrm{~km}$ long extending from As Seeb to the United Arab Emirates and ranging laterally between 10 and $40 \mathrm{~km}$ in width from the foothills of Al-Hajar Mountains to the sea. A $13 \mathrm{~km}$ long soil transect, almost perpendicular to the shore line, representing a catena was selected for the study. The catena extends from Nakhal (foothills of Al-Hajar mountains; N 23 $24^{\prime}$ E $\left.57^{\circ} 49^{\prime}\right)$ to Barka which locates at the coastline of Al-Batinah region (N $23^{\circ} 42$ E $57^{\circ} 55^{\prime}$; Figure 1). Five locations were chosen to represent the dominant soil types found along the transect. Soil pedons were examined and described using the standard procedures (Schoeneberger et al., 2002; Figure 2). A bucket auger was used for further investigation of the soil layers surrounding the pedons. Soil texture was estimated using the feel method (Thien, 1979; Figure 3). Soil color was determined using the Munsell color book and the percent gravel was estimated in the field (Figure 4). Soils were classified based on Soil Taxonomy (Soil Survey Staff, 2006). Soil samples were collected from selected horizons of each profile for laboratory analyses. Soil $\mathrm{pH}$ and EC were preliminarily measured in the field (EC1:2) using portable meters (Figure 5). In the lab, both $\mathrm{pH}$ and $\mathrm{ECe}$ were measured using the saturated paste method as proposed by Rhoades (1996). The presence of free carbonates were estimated using $10 \% \mathrm{HCl}$. Soil particle size distribution was determined by the hydrometer method of Gee and Bauder (1986). Soluble $\mathrm{Ca}^{2+}, \mathrm{Mg}^{2+}$, and $\mathrm{Na}^{+}$in the paste extract were measured using an inductively coupled plasma mass spectrometry (ICP), and sodium adsorption ratio (SAR) was calculated.

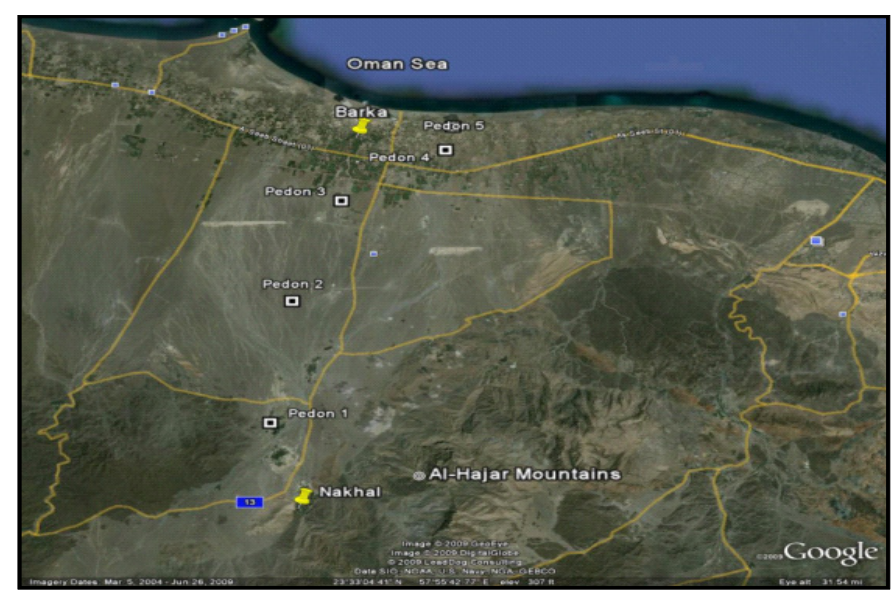

Fig. 1. Geographical location for the five soil pedons used for the study area.

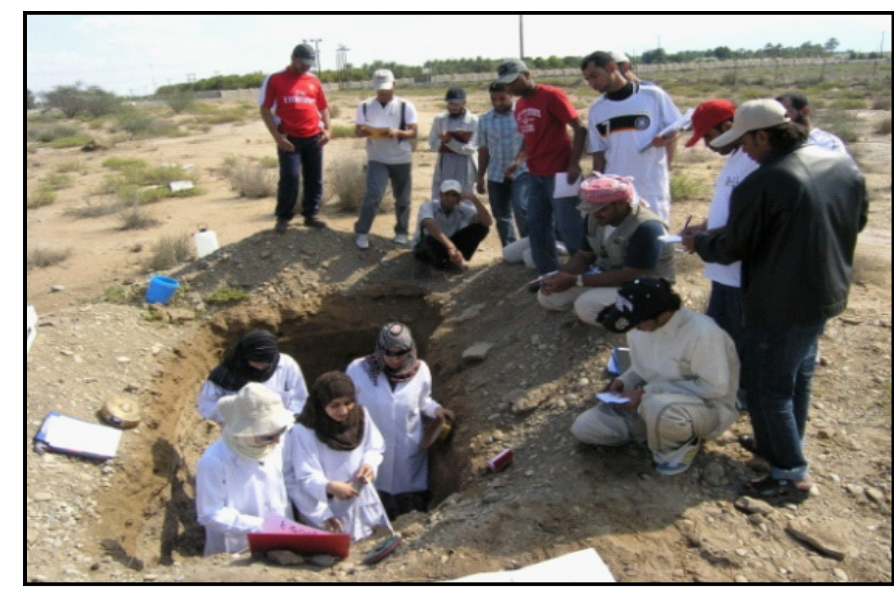

Fig. 2. Soil pedon preparation and profile description by the students.

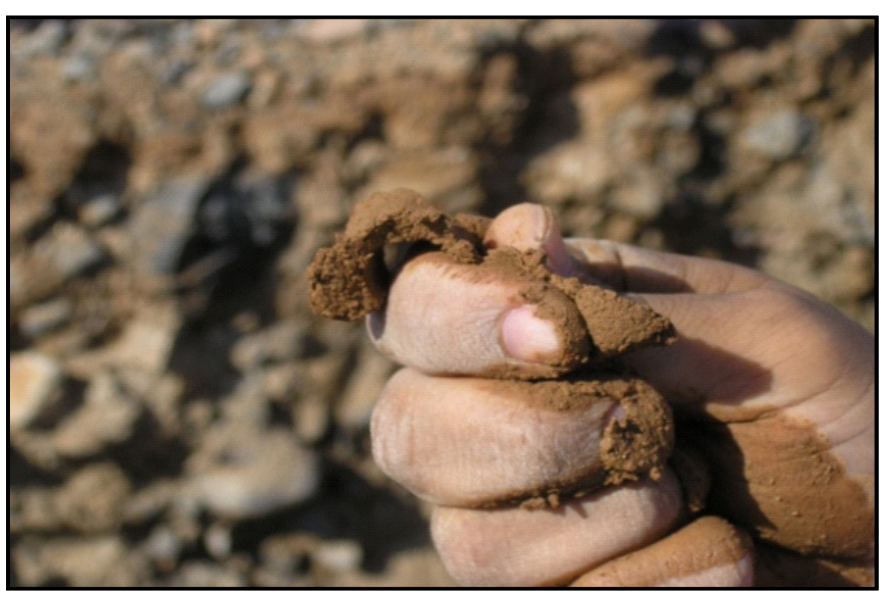

Fig. 3. Ribbon formation while estimating soil texture with the feel method.

Elevations for all sites were determined using a GPS receiver. The general Soil Map of the Sultanate of Oman, prepared by the Ministry of Agriculture in cooperation with FAO of the United Nations (Ministry of Agriculture and FAO, 1990), was used as a guide in the selection of the fieldwork sites and as a data base for the soils of the selected sites.

\section{Student Technical Reports (Example)}

Students were asked to collect the necessary soil samples needed for laboratory analyses. They were responsible for conducting the appropriate soil analyses. Students were then asked to discuss and interpretate the laboratory and field data. Finally, student's main assignment was to write a technical report emphasizing their understanding on how topography influences soil formation, as integrated with parent material, organisms, climate, and time. The following is an example of the final technical report that was expected from the students.

The soils of the study area developed mostly from an alluvium parent material derived from the Al-Hajar mountains limestone and ophiolites. The climate is arid, characterized by a long, hot 


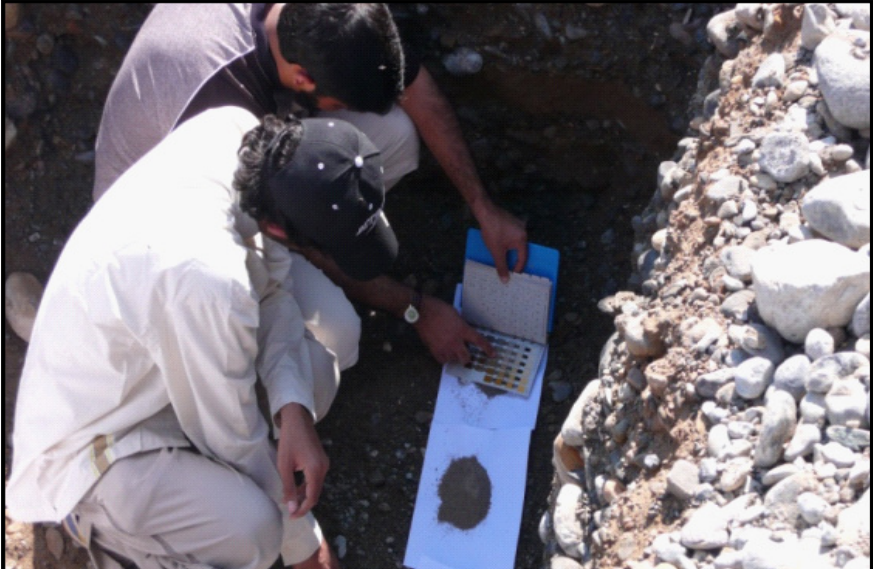

Fig. 4. Field determination of soil color using the Munsell color book.

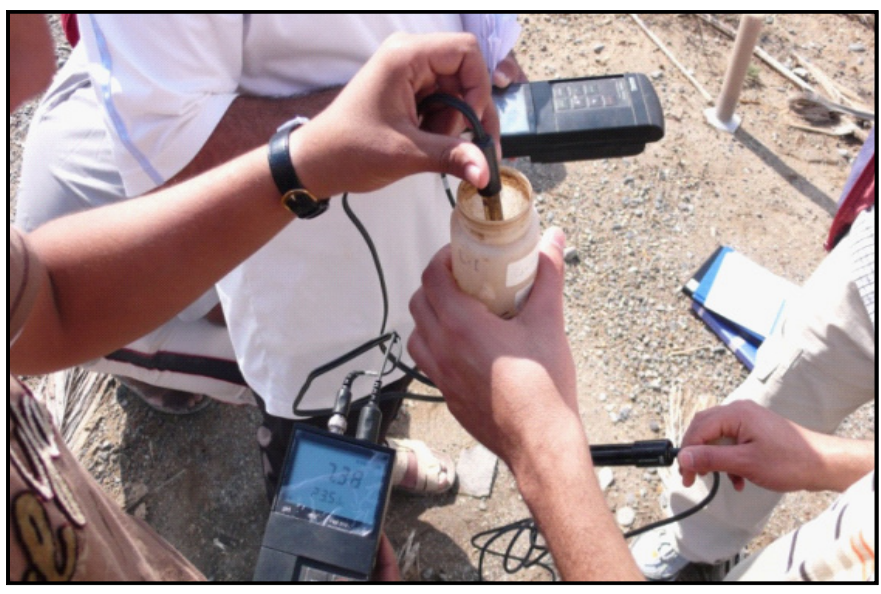

Fig. 5. Field determination of salinity using a portable EC meter.

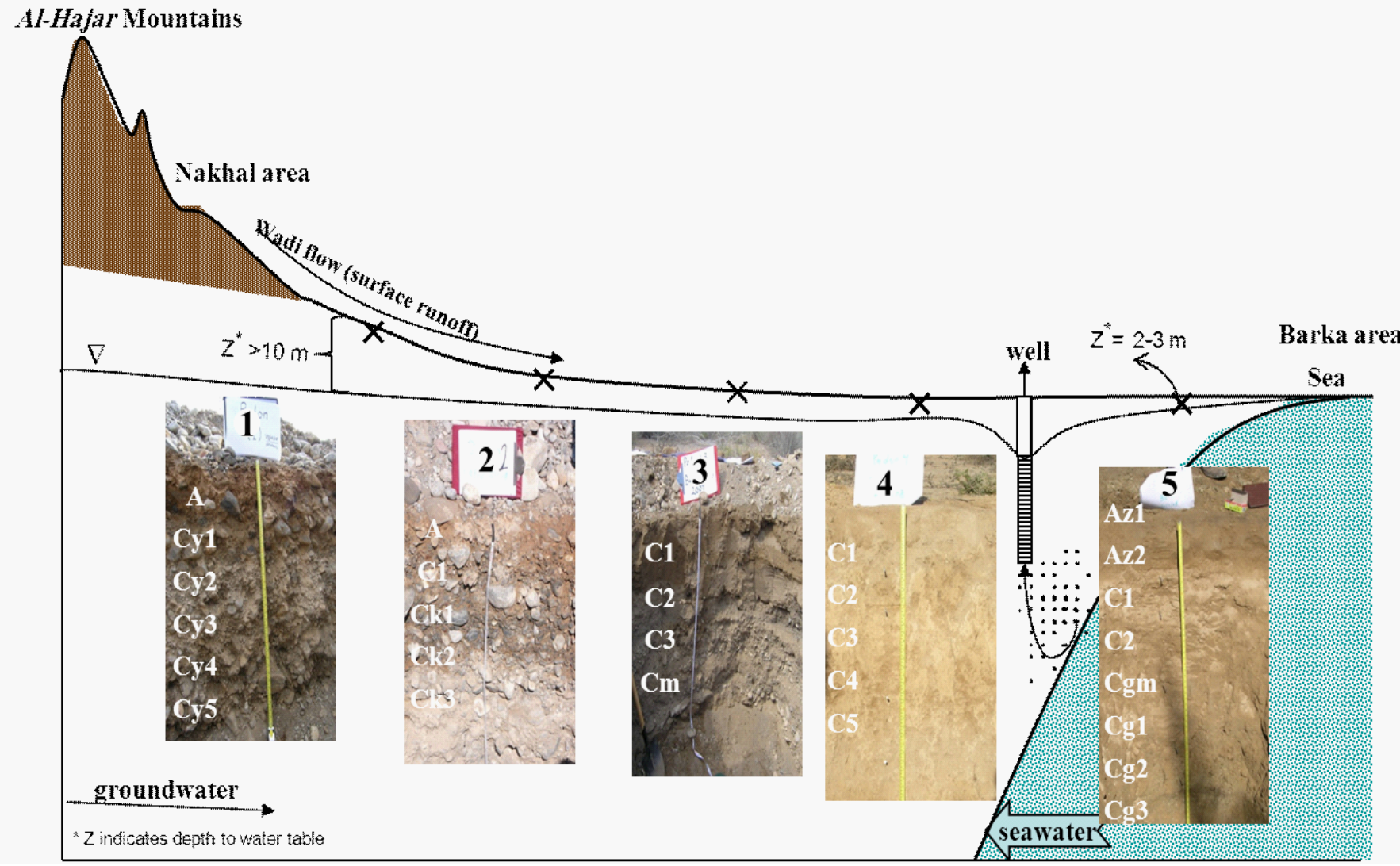

Fig. 6. Soil profiles in a catena with their horizons designations.

season beginning in April and ending in October. The soils are of aridic soil moisture contents with average annual rainfall of the area of $100 \mathrm{~mm}$ (MA and FAO, 1990). The mean annual temperature is $27^{\circ} \mathrm{C}$.

Detailed profile description for the different soils occurring along the catena is shown in Table 1 and Figure 6. A wide range of different soil types dominate the study area forming a sequence of gravelly typic Gypsiorthids (upstream at the foothills), typic Torriorthents, typic Torripsamments, typic Torrifluvents, and typic
Salorthids (downstream at the coastline). The majority of soils in Oman are of Aridisols and Entisols orders (MA and FAO, 1990). This is mainly due to water scarcity, limited vegetation, and erosion due to intense-short periods of rainfall which is a characteristic of desert soils. The prevailing of such conditions has made these soils less reactive to soil formation factors. The formation of shallow pedogenic horizons enriched with either calcium and/or gypsum was common in several soils located at the upstream of the catena. Shallow accumulation of soluble salts is common in Arid-zone soils 


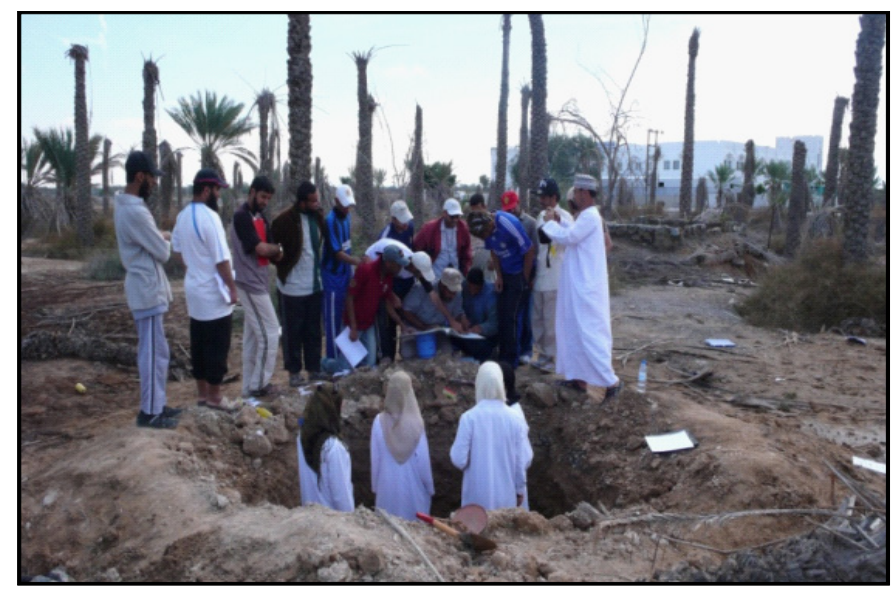

Fig. 7. Studying the properties and genesis of a salt-affected soil formed in one of the abandoned farms due to salinity. ments in soils developed in the floodplain. This was expected since wadis originating in the nearby Al-Hajar mountains deposit their load of sand and gravels closer to the foothills and finer materials before reaching the coast. Soil $\mathrm{pH}$ for the most dominate soils was around 8.0 with the exception of Typic Salorthids loam which had a relatively lower $\mathrm{pH}=7.6$. This alkaline range in soil $\mathrm{pH}$ is normal for soils of dry regions where there is no enough rain to leach the basic cations. Soil salinity values vary as low as 0.7 dS.m- 1 to extremely saline, up to 54 dS.m-1. The lower salinity in soils of the footslope to the toeslope and that of Torripsamments maybe attributed to the relatively higher leaching due to the sandy and coarser nature of these soils. Soil forming on the floodplain were salt effected and had the highest salinity levels and especially that of Salorthids (Figure 7). The presence of salts more soluble than gypsum is responsible for the arising of Salorthids formation (Soil Taxonomy, 1975). Table 2 shows the chemical compositions

Table 1. Physico-chemical characteristics for the upper layers of soil pedons with their morphological and topographical information.

\begin{tabular}{|c|c|c|c|c|c|c|c|c|c|c|c|c|}
\hline \multirow[t]{2}{*}{$\begin{array}{l}\text { Pedon } \\
\text { No. }\end{array}$} & \multirow[t]{2}{*}{ Taxa and phase } & \multirow[t]{2}{*}{$\begin{array}{c}\mathrm{ECe} \\
\left(\mathrm{dS} \mathrm{m}^{-1}\right) \dagger\end{array}$} & \multirow[t]{2}{*}{$\begin{array}{l}\text { Soil } \\
\mathrm{pH}\end{array}$} & \multirow[t]{2}{*}{$\begin{array}{c}\mathrm{HCl} \\
\ddagger\end{array}$} & \multicolumn{3}{|c|}{$\begin{array}{c}\text { Textural Analyses } \\
(\%)\end{array}$} & \multirow{2}{*}{$\begin{array}{c}\text { Rock } \\
\text { fragment } \\
s \\
(\%) \\
\end{array}$} & \multirow[t]{2}{*}{$\begin{array}{l}\text { Topographical } \\
\text { position }\end{array}$} & \multirow[t]{2}{*}{$\begin{array}{c}\text { Elevatio } \\
\mathrm{n}(\mathrm{m})\end{array}$} & \multirow{2}{*}{$\begin{array}{l}\text { Distance } \\
\text { from coast } \\
(\mathrm{km})\end{array}$} & \multirow[t]{2}{*}{$\begin{array}{c}\text { Main morphologica } \\
\text { Features }\end{array}$} \\
\hline & & & & & Sand & Silt & Clay & & & & & \\
\hline 1 & $\begin{array}{l}\text { Typic Gypsiorthids gravelly } \\
\text { loamy sand }\end{array}$ & 0.8 & 8.1 & 4 & 83 & 13 & 4 & 30 to 40 & Footslope & 285 & 15 & $\begin{array}{c}\text { Aggregated } \\
\text { accumulation of } \\
\text { gypsum }\end{array}$ \\
\hline 2 & $\begin{array}{l}\text { Typic Torriorthents gravelly } \\
\text { loamy sand }\end{array}$ & 0.9 & 8.0 & 5 & 87 & 7 & 6 & 40 to 45 & Toeslope & 118 & 10 & $\begin{array}{c}\text { Powdery and } \\
\text { clusters of } \mathrm{CaCO}_{3}\end{array}$ \\
\hline 3 & Typic Torripsamments sand & 0.7 & 7.9 & 5 & 94 & 3 & 3 & $\mathrm{Nil}$ & Floodplain & 27 & 5 & $\begin{array}{c}\text { Cemented layers of } \\
\text { sand in subsurface } \\
\text { layers }\end{array}$ \\
\hline 4 & $\begin{array}{c}\text { Typic Torrifluvents clay } \\
\text { loam }\end{array}$ & 7.0 & 8.1 & 4.5 & 39 & 34 & 27 & Nil & Floodplain & 5 & 1.0 & Nil \\
\hline 5 & Typic Salorthids loam & 54 & 7.6 & 4.5 & 52 & 38 & 10 & Nil & $\begin{array}{l}\text { Coastal plain } \\
\text { with shallow } \\
\text { water table }\end{array}$ & $\begin{array}{l}\text { flood } \\
\text { plain }\end{array}$ & 0.5 & $\begin{array}{c}\text { Surface salt crystals } \\
\text { with thin and hard } \\
\text { platy layers at } 50- \\
\mathrm{cm}\end{array}$ \\
\hline
\end{tabular}

$\dagger \mathrm{ECe}$ values in saturated paste extracts for the top soil $(0-25 \mathrm{~cm}) . \ddagger$ Scale of 1-5 ranging from no effervescent to violently effervescent.

Table 2. Selected chemical properties for the salt-affected soils.

\begin{tabular}{|c|c|c|c|c|c|c|c|}
\hline \multirow{2}{*}{$\begin{array}{c}\text { Pedon } \\
\text { No. }\end{array}$} & \multirow[t]{2}{*}{ Taxa and phase } & \multirow[t]{2}{*}{$\mathrm{EC}_{\mathrm{e}}\left(\mathrm{dS} \mathrm{m}^{-1}\right)$} & \multirow[t]{2}{*}{ Soil pH } & $\mathrm{Na}$ & $\mathrm{Ca}$ & $\mathrm{Mg}$ & \multirow[t]{2}{*}{ SART } \\
\hline & & & & \multicolumn{3}{|c|}{-----Mmol L-1----- } & \\
\hline 4 & Torrifluvents clay loam & 7.0 & 8.1 & 1097 & 609 & 202 & 14 \\
\hline 5 & Typic Salorthids loam & 54 & 7.6 & 9860 & 1294 & 1932 & 57 \\
\hline
\end{tabular}

$\dagger$ Where, $S A R=\frac{\left[\mathrm{Na}^{+}\right]}{\left(0.5\left[\mathrm{Ca}^{2+}\right]+0.5\left[\mathrm{Mg}^{2+}\right]\right)^{1 / 2}}$

where there is generally not enough water to leach soluble materials completely out from the profile. Moreover, the net moisture movement in these soils remains upwards due to high evaporation rates. In general, there were higher percent ages of coarser materials and in particular the sand fraction and rock fragments in soils developed at the shoulder and backslope positions of the catena. In contrast, there were finer materials with nil rock frag- for Torrifluvents and Salorthids including a calculated SAR values. Both soils had SAR values higher than 13 with ECe values greater than 4 dS.m- 1 and therefore were classified as saline-sodic soils. Depletion of ground-water due to over pumping and with low rainfall led to seawater intrusion and secondary salinization in many soils along the coastline of Al-Batinah (Abdelrahman et al., 1993). Secondary saliniztion is the type of salinity induced due 
to human activities. These activities may include poor irrigation practices or leaving the soil fallow for long periods which is the case for many of arid-zone soils such that of Al-Batinah (Hussain, 2006). Although topography is the dominant factor in influencing and differentiating the different soils along the catena, human activities have played a major role in the formation of salt affected soils along the coastline of Al-Batinah. Our study confirms that of Jenny (1941) who recognized that topography can never be completely isolated from other factors of soil formation. Hence, soil formation factors are interdependent rather than independent as they act on soils (Brady \& Weil, 2007).

\section{Conclusions}

Conducting this type of case studies is of valuable opportunity for soil science or other relevant students in understanding the concepts of soil-landscape relationships. Techniques gained from this work should help students in implementing the basic concepts of soil science, particularly the influence of topography, hydrology, and human activities on soils formation and development. Field exercises involving studying soils along a catena are of great educational value in understanding the different possible interactions among the soil formation factors. Combining field work with laboratory techniques is an excellent way in helping students broadening their knowledge in understanding the concepts of soil catena.

\section{Acknowledgments}

The authors thank Sultan Qaboos University for the financial and logistic support. Extended thanks go to Mr. Mansour AL-Haddabi, Mr. Hamad AL-Busaidi, and the undergraduate students for their contribution. Also, special thanks to Prof. Ray Weil at the University of Maryland for his comments on this manuscript.

\section{References}

Abdelrahman HA, A Lepiece, and V Macalinga (1993) Some physical and chemical characteristics of the Batinah Soils. Communications in Soil Science and Plant Analysis 24: 2293-2305.

Al-Rawahy HNS, J Rabee, and M Al-Amri (2006) Causes, origin, genesis and extent of soil salinity in the Sultanate of Oman. Pak J Agri Sci $43(1-2): 1-6$.

Brady N and R Weil (2007) The Nature and Properties of Soils. 14th Edition. Copyright (C) Pearson Education, Inc., Upper Saddle River, New Jersey USA.

Gee GW, and JW Bauder (1986) Particle-size analysis. p. 383-411. In A. Klute (ed.) Methods of soil analysis. Part 1. 2nd ed. Agron. Monogr. 9. ASA and SSSA, Madison, WI.

Jenny $H(1980)$ The soil resource, origin and behavior. Springer, New York.

Ministry of Agriculture and FAO (1990) General Soil Map of the Sultanate of Oman. Muscat, Oman.

Rhoades JD (1996) Salinity: Electrical conductivity and total dissolved solids. p. 417-435. In Sparks et al. (ed.) Methods of soil analysis. Part 3. SSSA book series: 5. ASA and SSSA, Madison, WI.

Schoeneberger PJ, DA Wysocki, EC Benham, and WD Broderson (2002) Field book for describing and sampling soils, version 2. Natural Resources Conservation Service, USDA, National Soil Survey Center, Lincoln, NE.

Soil Survey Staff (2006) Keys to Soil Taxonomy, 10th. Edition. USDANatural Resources Conservation Service, Washington, DC.

Thien SJ (1979) A flow diagram for teaching texture by-feel analysis. Journal of Agronomic Education. 8:54-55.

Weil R (2003) Getting To Know a Catena: A Field Exercise for Introductory Soil Science. J Nat Resour Life Sci Educ 32: 1-4. 